\title{
Optimization of chromium and tannic acid bioremediation by Aspergillus niveus using Plackett-Burman design and response surface methodology
}

\author{
Prachi Chaudhary', Vinod Chhokar ${ }^{2}$, Pragati Choudhary², Anil Kumar ${ }^{2}$ and Vikas Beniwal ${ }^{*}$
}

\begin{abstract}
A chromium and tannic acid resistance fungal strain was isolated from tannery effluent, and identified as Aspergillus niveus MCC 1318 based on its rDNA gene sequence. The MIC (minimum inhibitory concentration) of the isolate against chromium and tannic acid was found to be $200 \mathrm{ppm}$ and 5\% respectively. Optimization of physiochemical parameters for biosorption of chromium and tannic acid degradation was carried out by Plackett-Burman design followed by response surface methodology (RSM). The maximum chromium removal and tannic acid degradation was found to be 92 and $68 \%$ respectively by A. niveus. Chromium removal and tannic acid degradation was increased up to 11 and $6 \%$ respectively after optimization. Scanning electron microscopy (SEM) and Fourier transform infrared spectroscopy (FTIR) was used to investigate biosorption phenomena.
\end{abstract}

Keywords: Tannery effluent, A. niveus, Tannic acid, Chromium, Plackett-Burman, RSM

\section{Introduction}

Water is the important natural resource for all living forms. This natural resource is being polluted by rapid growth of population, metropolitanization and mechanization (Singanan et al. 2007). Industrialization leads to several environmental problems like water, land and air pollution. An extensive volume of wastewater originated from industries which are released into channels either untreated or inadequately treated causing water pollution.

The wide spread use of chromium in various products and application in different industrial processes has emitted considerable environmental contamination (Sultan and Hasnain 2007). Tanning industries widely used chromium compounds to convert animal skins and hides into leather, mainly chromium sulphate. Tanneries produced waste water in range of $30-35 \mathrm{~L} / \mathrm{kg}$ with total

\footnotetext{
*Correspondence: beniwalvikash@gmail.com

1 Department of Biotechnology, Maharishi Markandeshwar University, Mullana, Ambala 133207, India

Full list of author information is available at the end of the article
}

Chromium 23.3-42.5 mg/L. Other than tanning industry, metal finishing, petroleum refining, iron and steel production, inorganic chemicals production, textile manufacturing, and pulp-producing industries also contributed in chromium pollution. Cr (chromium) waste is liberated into the environment via deprived storage, leakage or improper treatment and disposal practices. In India, more than $50 \%$ of the total chromium effluent discharge originates from the leather, iron and steel industries (Garg et al. 2012, 2015). Human when exposed to $\mathrm{Cr}(\mathrm{VI})$ (hexavalent chromium) they may suffer from several health hazards such as allergic dermatitis, nasal irritation, renal tubular necrosis, eardrum perforation ulceration, skin irritation, lung carcinoma, epidermal dermatitis and increase risk of cytotoxic and genotoxic effects (cell death, cell transformation and gene mutation) and respiratory tract cancer (Camargo et al. 2005). Accumulation of $\mathrm{Cr}$ takes place mainly in spleen, liver, kidneys, and bone marrow. At high levels $\mathrm{Cr}$ damage cell membranes, disrupt cellular function, modify enzyme specificity, and damage structure of DNA (Farag and Zaki 2010; Smrithi and Usha 2012). 
It has adverse impacts on aquatic species as it penetrates into cell walls, accumulates in fish tissues. The pollution potential of the effluents from the tannery industry produces phytotoxic effects and high accumulation of heavy metals resulting in stress for plants. Trivalent chromium ( $\mathrm{Cr}(\mathrm{III}))$ is $10-100$ times less toxic than hexavalent chromium, the reason is that trivalent chromium complexes are impermeable through cellular membranes (Lu and Yang 1995).

Tannins are water soluble polymeric polyphenols having different molecular weight. Their molecular weight ranges from 500 to $3000 \mathrm{~g} / \mathrm{mol}$. Tannins have astringency property i.e. they precipitate phospholipids in cell membrane because of this cell wall becomes impermeable from solutions that increases its stability to water, bacteria and heat. Vegetable tanning is the oldest process used in the leather industries. Vegetable tannins are divided in two categories: hydrolysable tannins and condensed tannins. Hydrolysable tannins are esters of gallic acid (galotannins) or ellagic acid and are hydrolysed by acids or enzymes into monomers. Hydrolysable tannins (HT) cause necrosis of the liver, hemorrhagic gastroenteritis, jaundice, kidney damage with proximal tubular necrosis, photosensitization and death in severe cases (Dollahite et al. 1962; Murugan 2010). Condensed tannins are flavonoid monomers (Filippich et al. 1991; Bhat et al. 1998; Jadhav et al. 2011). The poisonous effects of Condensed tannins are less well known; in general CT reduces the digestive capacity. The tannin rich effluent is dark coloured because of the presence of tannins and its perseverance for a long time, unless microbial oxidation takes place. Tannins readily sink in the water bodies and reduce the availability of oxygen in deeper water layers. Tannins in irrigation water, makes it unfit and decrease the yield of crops. It inhibits the biodegradative enzymes and soil microorganisms and slow down the rate of decomposition of soil organic matter (Hernandez et al. 2005; Mahadevan and Muthukumar 1980). Biodegradation of condensed tannins is poorly understood due to its chemical complexity and reactivity. However, biodegradation of hydrolysable tannins produces important molecules like gallic acid and ellagic acid which shows a wide range of biological activities such as antimicrobial, antiviral, antioxidant and anticancer etc. (Chavez-Gonzalez et al. 2014; Choubey et al. 2015).

A number of researchers have reported the removal of chromium from the wastewater, but there is little information on tannic acid removal from the tannery wastewater. However, there is no report on the multiple toxicant removal. The present work aims to isolate indigenous predominant adapted fungal strains from tannery effluents which possess the ability to detoxify and degrade $\mathrm{Cr}$ and tannic acid from tannery effluent.

\section{Materials and methods}

\section{Isolation of fungal strain}

Effluent sample was collected from leather industry located at Karnal, Haryana, India. Samples of wastewater were taken from inlet of the treatment plant. Samples were mixed to get a composite sample and stored at $4{ }^{\circ} \mathrm{C}$ (Mahmood et al. 2013). The isolates were isolated using enrichment culture technique from tannery effluent samples (Sharma and Adholeya 2012). Chromium resistant and tannic acid degrading fungi were isolated separately. $10 \mathrm{~mL}$ effluent was enriched in $100 \mathrm{~mL}$ potato dextrose broth (PDB, pH 5.5) amended with $50 \mathrm{mg} / \mathrm{L}$ (50 ppm) filter sterilized $\mathrm{K}_{2} \mathrm{Cr}_{2} \mathrm{O}_{7}$ (Potassium dichromate) as $\mathrm{Cr}(\mathrm{VI})$ source and $0.1 \%$ filter sterilized tannic acid (as described by Chhokar et al. 2010), followed by incubation at $30{ }^{\circ} \mathrm{C}$ for $120 \mathrm{~h}$ at $120 \mathrm{rpm}$. After incubation, resistant fungi were isolated by serial dilution followed by spread plate technique on potato dextrose agar plates amended with $50 \mathrm{mg} / \mathrm{L}(50 \mathrm{ppm}) \mathrm{Cr}(\mathrm{VI})$ and $1 \mathrm{mg} / \mathrm{mL}(0.1 \%)$ tannic acid. The strain was sub-cultured at an interval of 4-5 weeks and routinely maintained on Potato Dextrose Agar (PDA) slants under refrigerated conditions.

A fungal spore inoculum was prepared by adding $2.5 \mathrm{~mL}$ of sterile distilled water containing $0.1 \%$ Tween 80 to a fully sporulated culture. The spores were dislodged using a sterile inoculation loop under strict aseptic conditions, and the number of spores in the suspension was counted using a Neubauer chamber. Finally, $1 \mathrm{~mL}(0.5 \mathrm{~mL}$ of each strain) of the prepared spore suspension was used as the inoculum, with a concentration of $5 \times 10^{9}$ spores (Beniwal et al. 2015).

\section{Screening of potential strain}

Screening was carried out for chromium removal and tannic acid degradation potentiality of fungal isolates under minimal salt medium $\left(\mathrm{K}_{2} \mathrm{HPO}_{4} 0.5 \mathrm{~g} / \mathrm{L}, \mathrm{KH}_{2} \mathrm{PO}_{4}\right.$ $0.5 \mathrm{~g} / \mathrm{L}, \mathrm{MgSO}_{4} 0.5 \mathrm{~g} / \mathrm{L}, \mathrm{NH}_{4} \mathrm{Cl} 1.0 \mathrm{~g} / \mathrm{L}$, Glucose $0.5 \mathrm{~g} / \mathrm{L}$, $\mathrm{pH}$ 5.5). Different concentrations of chromium (100, 150 and $200 \mathrm{ppm})$ and tannic acid (0.1, 0.25, 0.5\%) were amended in the medium along with effluent and inoculated with fungal isolates. Flasks were incubated at $30^{\circ} \mathrm{C}$, $120 \mathrm{rpm}$ for $120 \mathrm{~h}$. On the basis of atomic absorption spectroscopy and tannic acid assay potential strains were selected. Selected isolates were further screened out simultaneously for tolerance against $\mathrm{Cr}(\mathrm{VI})$ and tannic acid.

\section{Identification of the isolated fungal strain}

Total genomic DNA of the isolate was extracted according to the method of Wu et al. (2009). 18S rRNA gene fragment was amplified by PCR using the set of primers NS1 (5-GTAGTCATATGCTTGTCTC-3) and NS4 (5-CTTCCGTCAATTCCTTTAAG-3) designed to 
anneal to conserved regions of the fungi's $18 \mathrm{~S}$ rRNA. A $15-\mu \mathrm{L}$ reaction volume included $1 \mu \mathrm{L}(50 \mathrm{ng} / \mu \mathrm{L})$ template, $7.5 \mu \mathrm{L} 2 \times$ Taq PCR MasterMix, $5.9 \mu \mathrm{L}$ ddH2O, and $0.3 \mu \mathrm{L}$ of each primer $(10 \mu \mathrm{mol} / \mu \mathrm{L})$, performed in a Peltier Thermal cycler (M. J. Research, Inc, Japan) according to the following conditions: 35 cycles of $94{ }^{\circ} \mathrm{C}$ for $30 \mathrm{~s}$ (denaturation), primer annealing at $55^{\circ} \mathrm{C}$ for $50 \mathrm{~s}$, and $72{ }^{\circ} \mathrm{C}$ for $150 \mathrm{~s}$, and a final extension at $72{ }^{\circ} \mathrm{C}$ for $10 \mathrm{~min}$. PCR products were then electrophoresed on $1.5 \%$ agarose gels using $1 \times$ TAE buffer ( $40 \mathrm{mM}$ Tris acetate; $1 \mathrm{mM}$ EDTA; $\mathrm{pH} 8.0$ ), containing $200 \mathrm{ng} / \mathrm{mL}$ ethidium bromide to detect the product. Images were captured on a Syngene Bioimaging system (Syngene, U.K.). Sequencing of PCR products were conducted by excising the bands from the agarose and purifying the complementary DNA (cDNA) using AuPrep GelX kit (Life Technologies Ltd.). The purified cDNA was sequenced. The resulting sequences were analyzed and aligned using Blast Local Alignment Tool (BLAST) program at the National Centre for Biotechnology Information (NCBI).

\section{Selection of significant variables by Plackett-Burman design}

Plackett-Burman design containing eleven variables was selected to study their effect on chromium bioremidiation and tannic acid removal. Selected variables along their symbol code and range are shown in Additional file 1: Table S1. Among the nutrients, Glucose, $\mathrm{NH}_{4} \mathrm{Cl}$, $\mathrm{MgSO}_{4}, \mathrm{~K}_{2} \mathrm{HPO}_{4}$, chromium and tannic acid were selected. Furthermore, the physical parameters $\mathrm{pH}$, inoculums size, incubation period, temperature and agitation speed were tested. For each assay, the chromium removal and residual tannic acid was measured and calculated in terms of percentage (\%). The software Design Expert 9.0 (Stat Ease. Inc. ${ }^{\circledR}$, US) was used to analyze the experimental data.

\section{Optimization by response surface methodology and statistical design}

Box-Behnken is a response surface design, requires three level factorials, coded as $-1,0$, and +1 . Box-Behnken model generate designs with desirable statistical properties but, with only a fraction of the experiments required for a three-level factorial, the quadratic model is suitable for it. The coefficients of the quadratic model may be calculated using standard regression techniques (Francis et al. 2003). In Box-Behnken design, number of experiments is calculated by following equation:

$$
\mathrm{N}=\mathrm{k}_{2}+\mathrm{k}+\mathrm{cp}
$$

where $\mathrm{k}$ is the factor number and $\mathrm{cp}$ is the replicate number of the central point (Edrissi et al. 2008). The statistical software package 'Design Expert 6.0', Stat-Ease, Inc.,
Minneapolis, USA was used to analyze the experimental design.

The obtained data of chromium removal, and residual tannic acid was subjected to analysis of variance (ANOVA), suitable to the design of experiments. The mathematical relationship of the independent variables and the responses were calculated by the second order polynomial equation i.e.

$$
\begin{aligned}
Y= & \beta_{0}+\beta_{1} A+\beta_{2} B+\beta_{3} C+\beta_{4} D+\beta_{11} A^{2}+\beta_{22} B^{2} \\
& +\beta_{33} C^{2}+\beta_{44} D^{2}+\beta_{12} A B+\beta_{13} A C+\beta_{14} A D \\
& +\beta_{23} B C+\beta_{24} B D+\beta_{34} C D
\end{aligned}
$$

where $Y=$ predicted response; $\beta_{0}=$ intercept; $\beta_{1}, \beta_{2}, \beta_{3}$, $\beta_{4}=$ linear coefficients; $\beta_{11}, \beta_{22}, \beta_{33}, \beta_{44}=$ squared coefficients; $\beta_{12}, \beta_{13}, \beta_{14}, \beta_{23}, \beta_{24}, \beta_{34}=$ interaction coefficients and $A, B, C, D$ are coded value of variables to determine the optimum level for maximal degradation of tannic acid 3D graphs were produced to get to know the effect of selected variables individually and in combination (Beniwal et al. 2015).

\section{Tannic acid assay and analysis of chromium}

Tannic acid was measured by the method of Hagerman and Butler (Hagerman and Butler 1989). Briefly $3 \mathrm{~mL}$ of triethanolamine $(1 \%, \mathrm{v} / \mathrm{v})$ was added to $1 \mathrm{~mL}$ of filtered culture, followed by addition of $1 \mathrm{~mL} \mathrm{FeCl}{ }_{3}\left(0.01 \mathrm{M} \mathrm{FeCl}_{3}\right.$ in $0.01 \mathrm{~N} \mathrm{HCl}$ ) solution. The mixture was kept for $15 \mathrm{~min}$ at room temperature for color stabilization. Color was read at $530 \mathrm{~nm}$ against the blank by UV-Vis spectrophotometer, Model-2450 (Shimadzu, Japan).

Total chromium was estimated by atomic absorption spectrophotometer (SensAA GBC).

\section{Characterization of $\mathrm{Cr}(\mathrm{VI})$ biosorption on the basis of surface studies \\ Fourier transforms infrared (FTIR) spectroscopy}

FTIR spectrum study was carried out to explain the change in the functionalities of the microbial culture in the presence of chromium. The spectra were collected using Shimadzu equipped with diffuse reflectance accessory with the range of $400-4000 \mathrm{~cm}^{-1}$ (Tunali et al. 2006). The biomass was harvested by filtering the culture. The $4 \mathrm{~h}$ lyophilized sample was grounded in a pestle and mortar with $\mathrm{KBr}$. The background obtained from $\mathrm{KBr}$ disc was automatically took away from the sample discs. The spectra were composed using Perkin Elmer BX II system.

\section{Scanning electron microscopy}

Morphological changes resulting from the metal stress was examined by Scanning Electron Microscopy (SEM) (JSM-6510 OVL, Japan). Culture was centrifuged at 
$6000 \mathrm{rpm}$ for $15 \mathrm{~min}$. The supernatant was discarded and fungal beads pellet was washed 3-4 times with $0.1 \mathrm{M}$ phosphate buffer ( $\mathrm{pH}$ 7.2). After that fungal pellet was fixed in $2.5 \%$ glutaraldehyde and dehydrated with $30-90 \%$ ethanol. Final dehydration in $100 \%$ ethanol was carried out for 8-10 min and dried to remove moisture. Chromium treated and untreated (control) samples were coated with $90 \AA$ thick gold under vacuum to increase the electron conduction and to improve the quality of the micrographs. Coated cells were viewed at $15 \mathrm{kV}$ with scanning electron microscopy (Michalak et al. 2014).

\section{Results}

\section{Isolation, screening and identification of fungal strain}

Fifteen chromium resistance and tannic acid degrading fungal strains were isolated from the tannery effluent samples by continuous transfer on minimum salt medium amended with $50 \mathrm{ppm}$ filter sterilized $\mathrm{K}_{2} \mathrm{Cr}_{2} \mathrm{O}_{7}$ as $\mathrm{Cr}(\mathrm{VI})$ and $0.1 \%$ tannic acid as the sole carbon source. The isolates Cr 5 was selected among all the isolated strains for their fast growth rate and relatively higher resistance toward chromium and tannic acid. The MIC of the strain was found to be $200 \mathrm{ppm}$ and $1 \%$ for chromium and tannic acid respectively. During simultaneous screening $\mathrm{Cr}(\mathrm{VI})$ and tannic acid removal was found around 81 and $62 \%$ respectively.

Colonies of $\mathrm{Cr} 5$ on agar plate were dense, thin margin, conidial areas white with pale yellowish shade at the centre, reverse greyed-orange. The amplified partial $18 \mathrm{~S}$ rRNA gene was sequenced and compared with similar information available at the GenBank by an online alignment search. The BLASTn of the isolate was showing 98\% homology with Aspergillus niveus (KM613137.1) suggesting that the isolate is highly likely to be $A$. niveus. The sequence was submitted to GenBank with an accession number of KX129954. The strain has been deposited to Microbial Culture Collection, National Centre for Cell Science, India with a reference number MCC 1318.

\section{Selection of significant variables by Plackett-Burman design}

Table 1 Shows the Plackett-Burman experimental design of $A$. niveus and results obtained from experiments. The adequacy of the model was calculated and the variables showing statically significant effects were screened on the basis of \% contribution, coefficient estimate and $\mathrm{P}$ value. The variables with significant effects were those with a $\mathrm{P}<0.05$, selected for further optimization study. Extensive deviation was found in $\mathrm{Cr}(\mathrm{VI})$ reduction (59.399.9\%) and residual TA (12.4-92.0\%), which reflects the importance of medium optimization to accomplish high reduction. Cr concentration, with a probability value of 0.0043 and 0.033 , TA concentration $(0.0061,0.0232)$, glucose $(0.0032,0.0421)$, and $\mathrm{NH}_{4} \mathrm{Cl}(0.0042,0.0151)$ were found to have positive influence on removal and selected for further optimization studies (Table 2). The lower probability values indicate the more significant factors for $\mathrm{Cr}$ and tannic acid removal. Agitation speed exerted a negative effect on the responses. Including agitation speed all other insignificant variables were neglected and the optimum levels of the four variables, $(\mathrm{Cr}$, TA, glucose and $\mathrm{NH}_{4} \mathrm{Cl}$ ) were further determined by an $\mathrm{RSM}$ design. Rest of the variables were worked best at their middle value.

\section{Response surface methodology}

The experimental design was aimed to identify the best levels of the selected variables, i.e. $\mathrm{NH}_{4} \mathrm{Cl}(0.5-1.5 \mathrm{~g} / \mathrm{L})$, glucose $(0.2-0.8 \mathrm{~g} / \mathrm{L}), \mathrm{Cr}$ concentration $(50-200 \mathrm{ppm})$, and tannic acid concentration (5-50 ppm) (Additional

Table 1 Plackett Burman experimental design matrix of eleven variables

\begin{tabular}{|c|c|c|c|c|c|c|c|c|c|c|c|c|c|}
\hline Run & $X_{1}$ & $X_{2}$ & $x_{3}$ & $X_{4}$ & $X_{5}$ & $x_{6}$ & $x_{7}$ & $X_{8}$ & $X_{9}$ & $x_{10}$ & $X_{11}$ & $\%$ Cr removal & $\%$ residual TA \\
\hline 1 & 5 & 30 & 96 & 110 & 3 & 100 & 2.75 & 0.5 & 1 & 0.5 & 0.5 & 90.75 & 54.06 \\
\hline 2 & 7 & 20 & 144 & 180 & 1 & 150 & 5 & 0.8 & 0.5 & 0.2 & 0.2 & 74.83 & 74.73 \\
\hline 3 & 3 & 40 & 144 & 40 & 5 & 150 & 5 & 0.2 & 0.5 & 0.2 & 0.8 & 91.44 & 92.03 \\
\hline 4 & 3 & 40 & 144 & 180 & 1 & 50 & 0.5 & 0.8 & 0.5 & 0.8 & 0.8 & 59.32 & 12.49 \\
\hline 5 & 3 & 20 & 48 & 180 & 1 & 150 & 5 & 0.2 & 1.5 & 0.8 & 0.8 & 88.71 & 92.05 \\
\hline 6 & 7 & 40 & 48 & 40 & 1 & 150 & 0.5 & 0.8 & 1.5 & 0.2 & 0.8 & 99.57 & 70.8 \\
\hline 7 & 7 & 20 & 144 & 180 & 5 & 50 & 0.5 & 0.2 & 1.5 & 0.2 & 0.8 & 97.63 & 27.24 \\
\hline 8 & 7 & 40 & 144 & 40 & 1 & 50 & 5 & 0.2 & 1.5 & 0.8 & 0.2 & 97.21 & 74.73 \\
\hline 9 & 3 & 40 & 48 & 180 & 5 & 50 & 5 & 0.8 & 1.5 & 0.2 & 0.2 & 72.31 & 74.73 \\
\hline 10 & 3 & 20 & 144 & 40 & 5 & 150 & 0.5 & 0.8 & 1.5 & 0.8 & 0.2 & 94.15 & 55.95 \\
\hline 11 & 3 & 20 & 48 & 40 & 1 & 50 & 0.5 & 0.2 & 0.5 & 0.2 & 0.2 & 87.11 & 40.41 \\
\hline 12 & 7 & 20 & 48 & 40 & 5 & 50 & 5 & 0.8 & 0.5 & 0.8 & 0.8 & 60.16 & 74.73 \\
\hline 13 & 7 & 40 & 48 & 180 & 5 & 150 & 0.5 & 0.2 & 0.5 & 0.8 & 0.2 & 99.99 & 90.22 \\
\hline
\end{tabular}


Table 2 Screening of critical factors for $A$. niveus

\begin{tabular}{|c|c|c|c|c|c|c|c|c|}
\hline \multicolumn{5}{|l|}{ Chromium } & \multicolumn{4}{|l|}{ Tannic acid } \\
\hline Variable & Stdized effect & $\%$ contribution & $\begin{array}{l}\text { Coefficient esti- } \\
\text { mate }\end{array}$ & $P$ value & Stdized effect & $\%$ contribution & $\begin{array}{l}\text { Coefficient esti- } \\
\text { mate }\end{array}$ & $P$ value \\
\hline $\mathrm{pH}$ & 6.06 & 4.53 & 3.03 & 0.0089 & 7.47 & 2.23 & 3.73 & 0.4348 \\
\hline Temperature & 2.88 & 1.02 & 1.44 & 0.0187 & 8.32 & 2.77 & 4.16 & 0.4016 \\
\hline Incubation period & 1.12 & 0.16 & 0.56 & 0.0479 & -17.63 & 12.45 & -8.81 & 0.2112 \\
\hline Agitation speed & -6.14 & 4.66 & -3.07 & 0.0088 & -6.20 & 1.54 & -3.10 & 0.4935 \\
\hline Inoculum size & 1.49 & 0.27 & 0.74 & 0.0361 & 8.28 & 2.75 & 4.14 & 0.4028 \\
\hline Cr concentration & 12.49 & 19.27 & 6.25 & 0.0043 & 28.58 & 32.70 & 14.29 & 0.0333 \\
\hline TA concentration & 8.85 & 9.68 & 4.43 & 0.0061 & 30.98 & 38.44 & 15.49 & 0.0232 \\
\hline Glucose & 16.96 & 35.51 & 8.48 & 0.0032 & 8.87 & 13.15 & 4.44 & 0.0421 \\
\hline $\mathrm{NH}_{4} \mathrm{Cl}$ & 12.79 & 20.19 & 6.39 & 0.0042 & 1.82 & 0.13 & 0.91 & 0.0151 \\
\hline $\mathrm{MgSO} 4$ & 3.89 & 1.87 & 1.95 & 0.0138 & 3.37 & 0.46 & 1.69 & 0.6774 \\
\hline $\mathrm{K}_{2} \mathrm{HPO}_{4}$ & 4.80 & 2.84 & 2.40 & 0.0112 & 6.91 & 1.91 & 3.45 & 0.4593 \\
\hline
\end{tabular}

file 1: Table S2). Box Behnken experimental design of $A$. niveus with actual and predicted values was presented in Table 3. The second-order polynomial equation was used to find out the relationship between variables and response. The regression equation coefficients were calculated and data was fitted to a second-order polynomial equation.

\section{Model validation}

The acceptability of the model and fitness was estimated by ANOVA (analysis of variance) and regression coefficients for the experimental design used. The ANOVA of $A$. niveus (Table 4) for the quadratic model of residual tannic acid and $\mathrm{Cr}$ removal indicated the $\mathrm{F}$ value of 7275.21 and 8.73 respectively with a very low probability value (Pmodel $>\mathrm{F}=0.0001,0.0002$ respectively) indicates significant level at $95 \%$ confidence interval. At the same time, relatively lower value of coefficient of variation $(\mathrm{CV} \%)=1.67$ and 0.29 for $\mathrm{Cr}$ removal and residual tannic acid (TA) indicated a better precision and reliability of the experiments carried out. The determination coefficient $\left(\mathrm{R}^{2}\right)$ of the model (tannic acid; 0.90 and $\mathrm{Cr}$ removal 1.0) showed the good agreement between the experimental results and the theoretical values predicted by the model and it showed that the model was appropriate to represent the real relationship among the selected factors (Table 5). The insignificant lack of fit test also pointed out that the model was suitable to navigate the design space. The residuals were used to check the homogeneous variance assumption by plotting the (studentized) residuals against the predicted probability values. Normal probability plot of the residuals nearly followed a straight line that indicates a normal distribution of residuals (Fig. 1a, b). The final predictive equation was as follows:

$$
\begin{aligned}
\text { Cr removal }= & +88.66+0.089 * \mathrm{~A}-1.05 * \mathrm{~B}+3.29 \\
& * \mathrm{C}-0.17 * \mathrm{D}-0.24 * \mathrm{AB}-0.23 * \mathrm{AC} \\
& -2.18 * \mathrm{AD}+0.59 * \mathrm{BC}-0.80 * \mathrm{BD} \\
& -2.36 * \mathrm{CD}+0.16 * \mathrm{~A}^{2} \\
& +0.96 \mathrm{~B}^{2}-2.29 * \mathrm{C}^{2}-2.06 * \mathrm{D}^{2}
\end{aligned}
$$

$$
\begin{aligned}
\text { Residual TA }= & +26.26-0.028 * \mathrm{~A}+22.28 * \mathrm{~B}-0.048 \\
& * \mathrm{C}-8.083 \mathrm{E}-003 * \mathrm{D}-1.000 \mathrm{E}-002 \\
& * \mathrm{AB}+0.093 * \mathrm{AC}-0.064 * \mathrm{AD}-0.10 * \mathrm{BC} \\
& +0.000 * \mathrm{BD}+5.000 \mathrm{E}-003 * \mathrm{CD} 0.041 * \mathrm{~A}^{2} \\
& +0.33 * \mathrm{~B}^{2}+0.075 * \mathrm{C}^{2}+0.080 \mathrm{D}^{2}
\end{aligned}
$$

\section{Interactive effects of two variables}

The compassion of the response to the two interacting variables was represented by the three dimensional graphs by holding the other variable at the central values. On the basis of quadratic polynomial Eqs. (3 and 4) of the response surface methodology. The effect of each variable was further estimated by the use of perturbation plots to show how the response changes as each variable moves from the chosen reference point, with all other factors held at constant reference values (Liong and Shah 2005). Figure 2a shows the perturbation plot of $\mathrm{Cr}$ removal. Although all variable showed significant quadratic effects, the curve with the most prominent change was the perturbation curve of $\mathrm{NH}_{4} \mathrm{Cl}$ followed by metal dose (Chromium concentration). Glucose and tannic acid 
Table 3 Box-Behnken experimental design of A. niveus

\begin{tabular}{|c|c|c|c|c|c|c|c|c|}
\hline \multirow[t]{2}{*}{ Run } & \multirow[t]{2}{*}{ A: glucose $\mathrm{g} / \mathrm{L}$} & \multirow[t]{2}{*}{ B: tannic acid \% } & \multirow[t]{2}{*}{ C: metal dose ppm } & \multirow[t]{2}{*}{ D: $\mathrm{NH}_{4} \mathrm{Cl} \mathrm{g} / \mathrm{L}$} & \multicolumn{2}{|c|}{ Cr removal \% } & \multicolumn{2}{|c|}{ Residual TA \% } \\
\hline & & & & & $A *$ value & $\mathrm{P*}$ value & $A *$ value & $\mathrm{P}^{*}$ value \\
\hline 1 & 0 & +1 & -1 & 0 & 80.97 & 82.39 & 49.03 & 49.10 \\
\hline 2 & 0 & +1 & 0 & +1 & 86.11 & 85.54 & 49 & 48.94 \\
\hline 3 & -1 & -1 & 0 & 0 & 89.42 & 90.50 & 4.38 & 4.38 \\
\hline 4 & 0 & 0 & +1 & -1 & 89.98 & 90.13 & 26.32 & 26.37 \\
\hline 5 & +1 & 0 & 0 & +1 & 84.21 & 84.50 & 26.29 & 26.28 \\
\hline 6 & 0 & 0 & 0 & 0 & 89.84 & 88.66 & 26.3 & 26.26 \\
\hline 7 & +1 & 0 & -1 & 0 & 83.66 & 83.55 & 26.33 & 26.31 \\
\hline 8 & -1 & 0 & -1 & 0 & 83.81 & 82.91 & 26.59 & 26.55 \\
\hline 9 & 0 & 0 & -1 & +1 & 83.26 & 83.21 & 26.47 & 26.45 \\
\hline 10 & +1 & 0 & 0 & -1 & - & & - & \\
\hline 11 & +1 & +1 & 0 & 0 & 89.54 & 88.57 & 48.84 & 48.88 \\
\hline 12 & 0 & 0 & 0 & 0 & 90.61 & 88.66 & 26.26 & 26.26 \\
\hline 13 & 0 & $0-1$ & 0 & +1 & 88.85 & 89.25 & 4.47 & 4.39 \\
\hline 14 & 0 & 0 & +1 & +1 & 85.67 & 85.06 & 26.27 & 26.37 \\
\hline 15 & 0 & 0 & 0 & 0 & 85.76 & 88.66 & 26.3 & 26.26 \\
\hline 16 & 0 & 0 & -1 & -1 & 78.12 & 78.82 & 26.54 & 26.48 \\
\hline 17 & 0 & 0 & 0 & 0 & 89.14 & 88.66 & 26.28 & 26.26 \\
\hline 18 & +1 & -1 & 0 & 0 & 90.62 & 91.16 & 4.29 & 4.34 \\
\hline 19 & +1 & 0 & +1 & 0 & 89.40 & 89.67 & 26.45 & 26.39 \\
\hline 20 & -1 & 0 & 0 & +1 & 88.13 & 88.69 & 26.4 & 26.47 \\
\hline 21 & 0 & +1 & 0 & -1 & 88.51 & 87.48 & 48.98 & 48.96 \\
\hline 22 & 0 & -1 & -1 & 0 & 86.73 & 85.68 & 4.26 & 4.34 \\
\hline 23 & 0 & -1 & +1 & 0 & 91.94 & 91.08 & 4.45 & 4.45 \\
\hline 24 & -1 & 0 & +1 & 0 & 90.48 & 89.95 & 26.34 & 26.26 \\
\hline 25 & -1 & +1 & 0 & 0 & 89.31 & 88.88 & 48.97 & 48.95 \\
\hline 26 & 0 & 0 & 0 & 0 & 87.91 & 88.66 & 26.17 & 26.26 \\
\hline 27 & -1 & 0 & 0 & -1 & 84.38 & 84.66 & 26.28 & 26.35 \\
\hline 28 & 00 & -1 & 0 & -1 & 88.06 & 87.99 & 4.45 & 4.41 \\
\hline 29 & 00 & +1 & +1 & 0 & 88.54 & 90.15 & 48.81 & 48.80 \\
\hline
\end{tabular}

$A^{*}$ value actual value, $P^{*}$ value predicted value

Table 4 Analysis of variance (ANOVA) of A. niveus for the fitted quadratic polynomial model for residual tannic acid and chromium

\begin{tabular}{lllllll}
\hline Response variable & Source & Sum of squares & Degree of freedom & Mean square & F value & P value prob $>$ F \\
\hline Tannic acid & Model & 5956.30 & 14 & 425.45 & 72757.21 & $<0.0001^{\mathrm{a}}$ \\
& Lack of fit & 0.064 & 9 & $7.149 \mathrm{E}-003$ & 2.45 & $0.2016^{\mathrm{b}}$ \\
& Pure error & 0.012 & 4 & $2.920 \mathrm{E}-003$ & & \\
& Cor total & 5956.38 & 27 & 18.51 & 8.73 & 0.40 \\
Chromium & Model & 259.18 & 14 & 1.46 & 3.60 & $0.0804^{\mathrm{b}}$ \\
& Lack of fit & 13.13 & 9 & & & \\
& Pure error & 14.42 & 27 & & & \\
\hline
\end{tabular}

\footnotetext{
a Significant

${ }^{b}$ Non significant
} 
Table 5 Statistical significance of residual tannic acid and chromium

\begin{tabular}{lcc}
\hline Model terms & Chromium & Tannic acid \\
\hline Std. dev. & 1.46 & 0.076 \\
Mean & 87.25 & 26.48 \\
\%CV & 1.67 & 0.29 \\
PRESS & 107.81 & 0.46 \\
R-squared & 0.9039 & 1.00 \\
Adj R-squared & 0.8004 & 1.00 \\
Pred R-squared & 0.6240 & 0.9999 \\
Adeq precision & 11.580 & 799.719 \\
\hline
\end{tabular}

was found to be the least prominent variable compared to the other variables. The response surface curves are plotted to explain the interaction of the variables and to determine the optimum level of each variable to reach a maximum response. Figure 3a clearly demonstrates that $\mathrm{Cr}$ removal was sensitive even to small changes in $\mathrm{NH}_{4} \mathrm{Cl}$ concentration with a maximum response at $1.10 \mathrm{~g} / \mathrm{L}$. $\mathrm{Cr}$ removal increases with increase of metal dose. Optimum metal dose was recorded at $200 \mathrm{ppm}$ (Fig. 3a). The interactive influence of $\mathrm{NH}_{4} \mathrm{Cl}$-tannic acid and metal doseglucose on $\mathrm{Cr}$ removal is illustrated in Fig. 3b, c. Three dimensional response surface plots of $A$. niveus demonstrated that tannic acid and glucose had no significant effect on $\mathrm{Cr}$ removal.
Figure $2 \mathrm{~b}$ showed that only tannic acid concentration showed significant effect on residual tannic acid. However, the other three factors did not have any significant role. Figure 4 shows that the residual tannic acid increases with an increase in TA concentration. However, other factors did not show any significant effect on the response (Fig. 4).

\section{Characterization of $\mathrm{Cr}(\mathrm{VI})$ biosorption on the basis of surface studies}

The evaluation of morphological changes in response to $\mathrm{Cr}$ biosorption in $A$. niveus was performed by scanning electron microscopy (SEM). It was observed that after incubation of $96 \mathrm{~h}$, the hyphae were cylindrical, septate, and branched. However in the presence of $180 \mathrm{mg} / \mathrm{l}$ of chromium, there was complete disruption and disintegration of mycelium in comparison to control (Additional file 1: Figure S1).

The FTIR spectra $\left(400-4000 \mathrm{~cm}^{-1}\right)$ of $\mathrm{Cr}(\mathrm{VI})$ loaded $A$. niveus was studied to confirm the presence of functional groups that are usually responsible for the biosorption process (Additional file 1: Figure S2). The frequencies of the spectrum bands and their assignments are listed in Additional file 1: Table S3. Peak frequencies in between 3429 and $3435 \mathrm{~cm}^{-1}$ attributed to $-\mathrm{OH}$ of glucose and $-\mathrm{NH}$ stretching of the protein and acetamide group. Changes were also detected in the absorption peak shifted at $1639 \mathrm{~cm}^{-1}$ corresponding to amide I (protein C-O stretching). A shift in the wave number $2367 \mathrm{~cm}^{-1}$
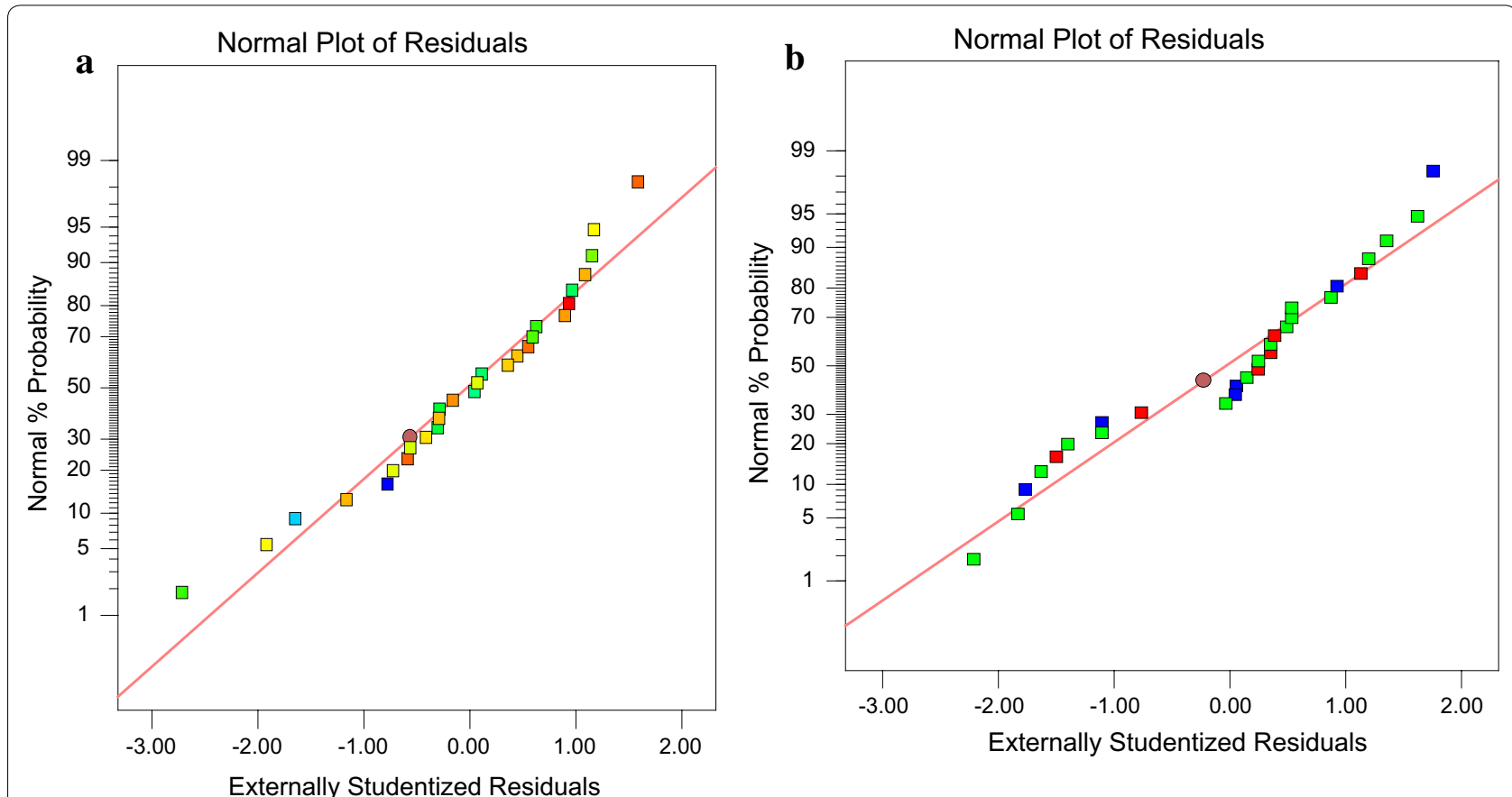

Fig. 1 Normal plot of studentized residuals verses normal \% probability of A. niveus for bearing the experiment for a $\mathrm{Cr}(\mathrm{VI})$ and $\mathbf{b}$ residual tannic acid 

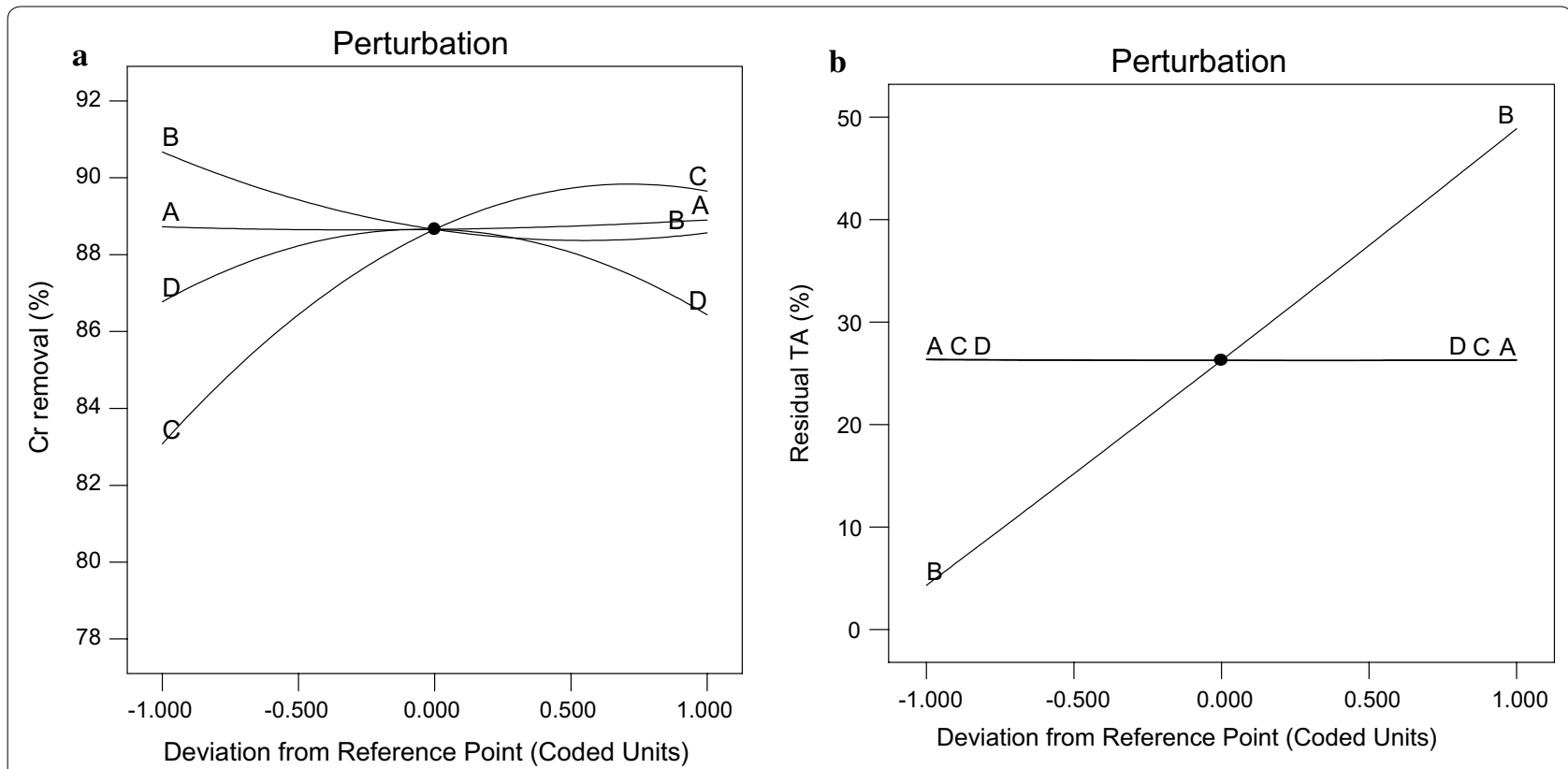

Fig. 2 Overlay plot of perturbation of A. niveus for $\mathbf{a} \mathrm{Cr}(\mathrm{VI})$ and $\mathbf{b}$ Residual tannic acid. A—glucose, B — tannic acid, $\mathrm{C}$-metal dose and D—NH ${ }_{4} \mathrm{Cl}$

was due to the $-\mathrm{CH}$ stretching of methyl and methylene groups. A peak in between 617 and $669 \mathrm{~cm}^{-1}$ was the result of $-\mathrm{CH}$ bending of alkenes.

\section{Discussion}

A total number of 15 fungi were isolated from tannery effluent samples. Cr 5, identified as A. niveus was found to be the most efficient isolate. Shugaba et al. (2010) isolated $A$. niger and $A$. parasiticus from the tannery sludge sample. Srivastava and Thakur (2006) reported Aspergillus sp. from tannery effluent. Das and Santra (2008) isolated A. flavus from Kolkata tannery effluent.

$\mathrm{Cr}$, TA, glucose and $\mathrm{NH}_{4} \mathrm{Cl}$ were selected among 11 variables by using Plackett-Burman design. Generally, lower probability value (less than 0.05 ) of a parameter indicated higher significance of that parameter. A positive coefficient indicated that the higher concentrations of the variable is best for increasing $\mathrm{Cr}(\mathrm{VI})$ removal and residual tannic acid, whereas negative values indicated the vice versa (Pulimi et al. 2012). Mohan et al. (2013); Costa Souza et al. (2015) and Melo et al. (2014) found TA significant for tannase production by Aspergillus sp. in Plackett-Burman study. Mabrouk et al. (2014) studied Cr reduction by Halomonas sp. M-Cr by applying PlackettBurman study and found that glucose significantly affects $\mathrm{Cr}$ removal in tannery effluent.

Mohan et al. (2014) also observed that with increase of metal dose $\mathrm{Cr}$ removal increases in A. flavus. Masood and Malik (2011) also find out that chromium adsorption was increased by Bacillus sp. FM1 with increasing metal concentration. This may be due to the interaction and binding affinity of chromium with sequestering sites of the organism increase with increased chromium concentration. Metal accumulation by fungi increases with increasing in initial metal ion concentration. This may be possibly due to increase electrostatic interactions of metal ions on the cell surface. Under suitable growth medium Aspergillus sp. produce spherical mycelia which help in metal accumulation (Prasenjit and Sumathi 2005). Karaca et al. (2010) reported that maximum Pb biosorption was occurred at $\mathrm{pH} 5$ by $A$. niveus.

The capability of microorganisms to degrade tannins has been featured to the construction of tannase, an important enzyme able of catalyzing gallotannins to gallic acid and glucose (Ilori et al. 2007; Beniwal et al. 2013). In Bacillus sphaericus, with the increase of tannic acid tannase production increases i.e. tannic acid degradation increases (Raghuwanshi et al. 2011). A. niger strains were able to grow in a high concentration of tannic acid (10\%). The highest tannase production by $A$. niger was occurred at 5\% tannic acid and response surface plots suggested that even more tannase production could be obtained when increasing the tannic acid concentration. The results of the present study are in accordance with the previous report of Rodriguez-Duran et al. (2011). Sharma et al. (2007) also obtained the maximum tannic acid degradation at $5 \%$ tannic acid by $A$. niger. Tannins have a property to form complexes with fungal or bacterial exozymes, this is how tannins slow down the biodegradation process. Tannins also form complexes with 

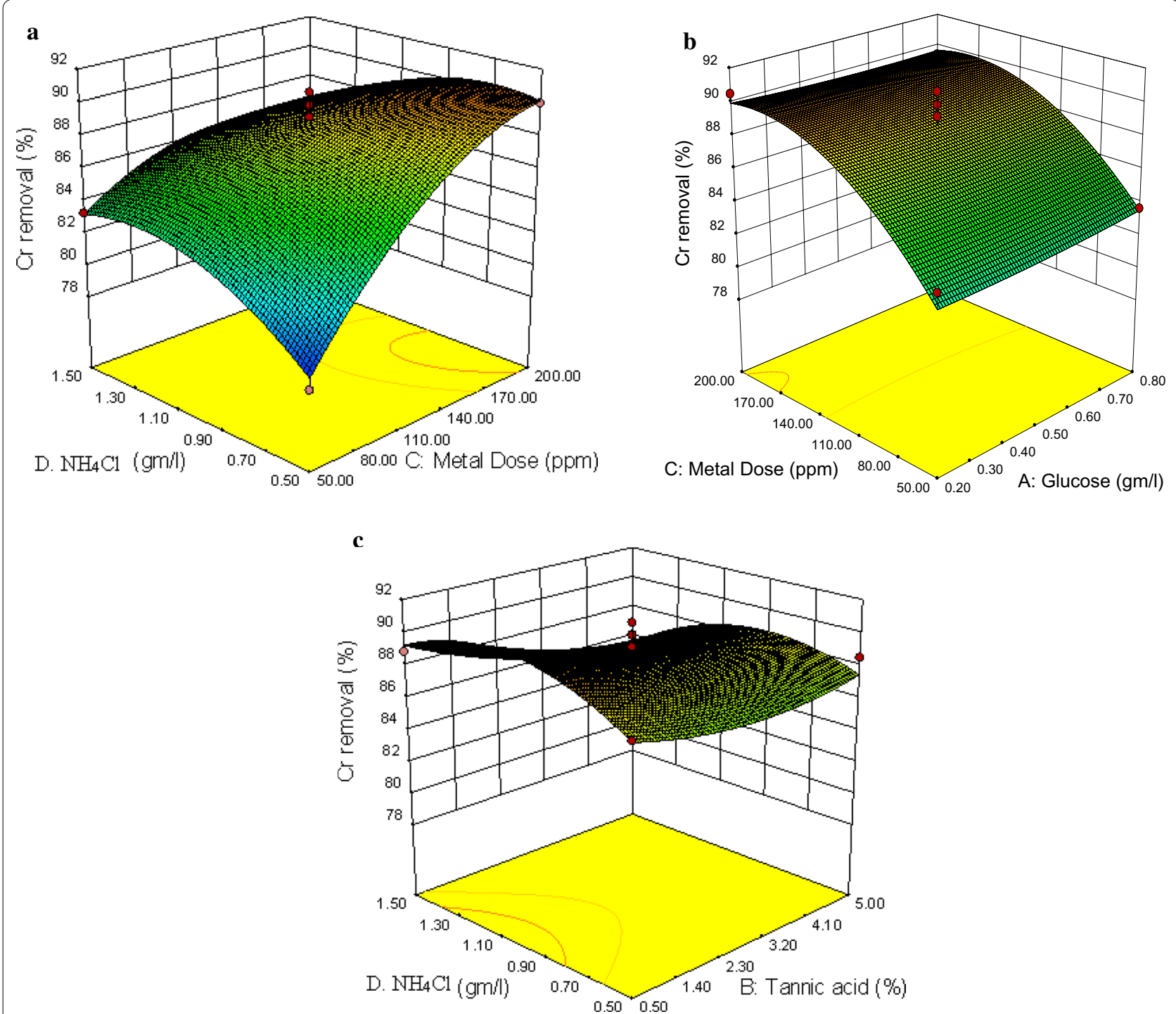

Fig. 3 Three dimensional plots of A. niveus. a Three-dimensional plot of residual $\mathrm{Cr}(\mathrm{VI})$ as a function of metal dose and glucose at constant tannic acid $(2.75 \%)$ and $\mathrm{NH}_{4} \mathrm{Cl}(1 \mathrm{~g} / \mathrm{L})$. b Three-dimensional plot of residual $\mathrm{Cr}(\mathrm{Vl})$ as a function of metal dose and tannic acid at constant glucose $(0.5 \mathrm{~g} / \mathrm{L})$ and $\mathrm{NH}_{4} \mathrm{Cl}(1 \mathrm{~g} / \mathrm{L})$. $\mathbf{c}$ Three-dimensional plot of residual $\mathrm{Cr}(\mathrm{VI})$ as a function of $\mathrm{NH}_{4} \mathrm{Cl}$ and metal dose at constant glucose $(0.5 \mathrm{~g} / \mathrm{L})$ and tannic acid $(2.75 \%)$

metals (Field and Lettinga 1992). Tannic acid has chelating property, so it is possible that chromium was chelated by tannic acid in the medium. Ammonium chloride did not show any effect on residual tannic acid. This is probably due to the absorption of inorganic ions and the possibility of formation of complexes between tannins and protein structures. Therefore, significant variables were subsequently evaluated (Paranthaman et al. 2009; Mondal and Pati 2000). Venil et al. (2011) reported maximum removal at the minimum levels of $\mathrm{NH}_{4} \mathrm{Cl}$ in Bacillus sp.

Scanning electron microscopy (SEM) and Fourier transform infrared spectroscopy (FTIR) was used to investigate adsorption phenomena. A disruption and disintegration of mycelium was found in SEM (Additional file 1: Figure S1). This was probably due to the precipitation of $\mathrm{Cr}$ within the matrix of mycelium of fungi (Verma et al. 2011).

Peak frequencies in between 3429 and $3435 \mathrm{~cm}^{-1}$ attributed to $-\mathrm{OH}$ of glucose and $-\mathrm{NH}$ stretching of the protein and acetamide group. Similar observations were made by Tunali et al. (2005) in Neurospora crassa. Manasi and Lolly (2014) also reported the presence of $\mathrm{OH},-\mathrm{CH}, \mathrm{C}-\mathrm{O}$ at their respective wavelengths of 3422 , 1210 and $2926 \mathrm{~cm}^{-1}$ in A. niger. Khambhaty et al. (2009) 


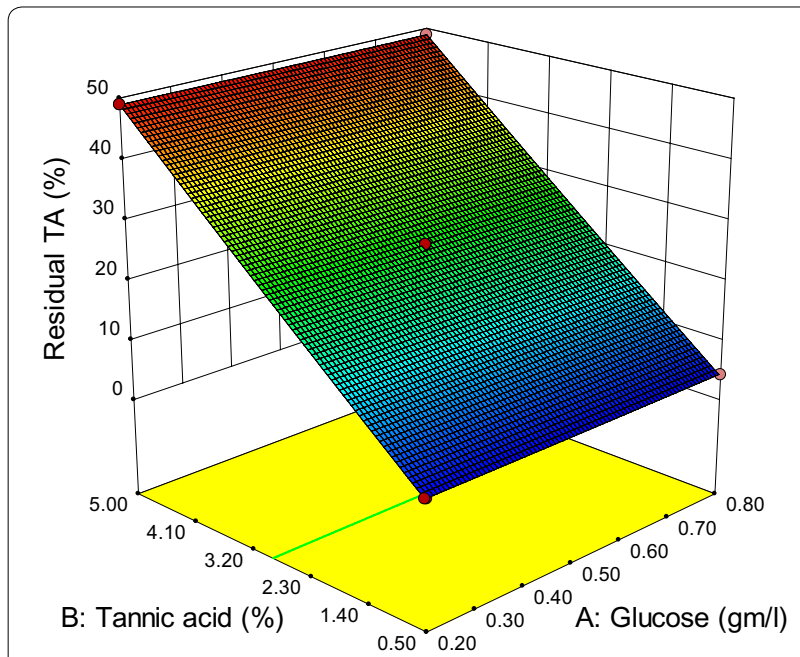

Fig. 4 Three-dimensional plot of residual tannic acid as a function of tannic acid and glucose at constant $\mathrm{NH}_{4} \mathrm{Cl}(1.0 \mathrm{~g} / \mathrm{L})$ and metal dose (125 ppm)

reported the participation of $-\mathrm{OH}$ (hydroxyl group), $-\mathrm{CH}_{2}$ (alkane group), $-\mathrm{NH}_{3}$ (amino group) and phosphorous groups (-P) for $\mathrm{Cr}(\mathrm{VI})$ ) binding to Aspergillus sp. The FTIR spectra showed the presence of ionizable functional groups (i.e., carboxyl, hydroxyl, phosphate and amino groups, methyl and methylene) that are able to interact with metal ions (Sethuraman and Balasubramanian 2010).

The present study indicates bioremediation potential of A. niveus against $\mathrm{Cr}$ and tannic acid degradation in tannery effluent. The maximum $\mathrm{Cr}(\mathrm{VI})$ removal and tannic acid degradation was found to be 92 and $68 \%$ respectively at $1.10 \mathrm{~g} / \mathrm{L} \mathrm{NH}_{4} \mathrm{Cl}, 200 \mathrm{ppm} \mathrm{Cr}$ concentration, $0.2 \mathrm{~g} / \mathrm{L}$ glucose and at $5 \%$ TA concentration by $A$. niveus. $\mathrm{Cr}(\mathrm{VI})$ removal and tannic acid degradation was increased up to 11 and $6 \%$ respectively after optimization. Hernandez et al. reported $67 \%$ tannic acid degradation by $A$. niger. Shugaba et al. (2010) reported chromium removal and tannic acid degradation by the immobilized beads of spores of A. niger and A. paraciticus and found 97\% chromium removal. Sharma and Adholeya (2012) reported $99 \%$ chromium removal by $A$. lentulus. Mishra and Malik (2012) reported $71 \% \mathrm{Cr}$ removal by A. lentulus. Srivastava and Thakur (2006) observed $70 \%$ chromium removal by Aspergillus sp. SEM and FTIR were used to investigate biosorption of chromium by $A$. niveus. According to these observations $A$. niveus can be used in treatment of chromium and tannic acid rich industrial effluent. The microbe based technology for the removal of metals from the waste water is a cost-effective and easy to use process and has great potential for future applications.
Up to best of our knowledge $A$. niveus is firstly isolated from tannery effluent and there is no report available on $A$. niveus for chromium removal and tannic acid degradation. However one report on $\mathrm{Pb}$ removal is available (Karaca et al. 2010).

\section{Additional file}

Additional file 1. Additional tables and figures.

\section{Abbreviations \\ RSM: response surface methodology; ANOVA: analysis of variance; SEM: scan- ning electron microscopy; FTIR: Fourier transform infrared spectroscopy; TA:} tannic acid.

\section{Authors' contributions}

Planning and designing of study: $V B$; experimentation: $P^{1}$; result analysis: $P C^{1}, V B, A K, V C, P C^{2}$; manuscript drafting: $P^{1}$, VB. All authors contributed in the final approval of manuscript. All authors read and approved the final manuscript.

\section{Author details}

${ }^{1}$ Department of Biotechnology, Maharishi Markandeshwar University, Mullana, Ambala 133207, India. ${ }^{2}$ Department of Bio \& Nano Technology, Guru Jambheshwar University of Science \& Technology, Hisar, Haryana 125001, India.

\section{Acknowledgements}

The authors thank Chairperson, Department of Bio \& Nano Technology, Guru Jambheshwar University of Science \& Technology, Hisar for providing necessary laboratory facilities to carry out this work.

\section{Competing interests}

The authors declare that they have no competing interests.

\section{Availability of data and materials}

We conducted experiments and data generated. All data is shown in figures, tables and additional file.

\section{Consent for publication}

Not applicable.

\section{Ethical approval}

This article does not contain any studies concerned with experimentation on human or animals.

\section{Publisher's Note}

Springer Nature remains neutral with regard to jurisdictional claims in published maps and institutional affiliations.

Received: 18 August 2017 Accepted: 2 November 2017 Published online: 14 November 2017

\section{References}

Beniwal V, Kumar A, Sharma J, Chhokar V (2013) Recent advances in industrial application of tannases: a review. Recent Pat Biotechnol 7(3):228-233 Beniwal V, Sharma A, Marwah S, Goel G (2015) Use of chickpea (Cicer arietinum L.) milling agrowaste for the production of tannase using co-cultures of Aspergillus awamori MTCC 9299 and Aspergillus heteromorphus MTCC 8818. Ann Microbiol 65(3):1277-1286

Bhat TK, Singh B, Sharma OP (1998) Microbial degradation of tannins - a current perspective. Biodegradation 9(5):343-357 
Camargo FA, Okeke BC, Bento FM, Frankenberger WT (2005) Diversity of chromium-resistant bacteria isolated from soils contaminated with dichromate. Appl Soil Ecol 29(2):193-202

Chavez-Gonzalez ML, Guyot S, Rodríguez-Herrera R, Prado-Barragán A, Aguilar CN (2014) Production profiles of phenolics from fungal tannic acid biodegradation in submerged and solid-state fermentation. Process Biochem 49(4):541-546

Chhokar V, Sangwan M, Beniwal V, Nehra K, Nehra KS (2010) Effect of additives on the activity of tannase from Aspergillus awamori MTCC9299. Appl Biochem Biotechnol 160(8):2256-2264

Choubey S, Varughese LR, Kumar V, Beniwal V (2015) Medicinal importance of galliacid and its ester derivatives: a patent review. Pharm Pat Anal 4(4):305-315

Costa Souza PN, Costa Maia N, Guimarães LH, Resende ML, Cardoso PG (2015) Optimization of culture conditions for tannase production by Aspergillus sp. GM4 in solid state fermentation. Acta Sci Biol Sci $37(1): 23-30$

Das S, Santra SC (2008) Characterization of simultaneous bio-accumulation and bio-reduction of hexavalent Chromium by an Aspergillus flavus isolate (ESTF-241). J Mycopathol Res 46(1):77-80

Dollahite JW, Pigeon RF, Camp BJ (1962) The toxicity of gallic acid, pyrogallol, tannic acid, and Quercus havardi in the rabbit. Am J Vet Res 23:1264

Edrissi M, AsI NR, Madjidi B (2008) Interaction of mefenamic acid with cobalt (II) ions in aqueous media: evaluation via classic and response surface methods. Turk J Chem 32(4):505-519

Farag S, Zaki S (2010) Identification of bacterial strains from tannery effluent and reduction of hexavalent chromium. J Environ Biol 31(5):877

Field JA, Lettinga G (1992) Toxicity of tannic compounds to microorganisms. In: Plant polyphenols. Springer, Berlin, pp 673-692

Filippich LJ, Zhu J, Oelrichs P, Alsalami MT, Doig AJ, Cao GR, English PB (1991) Hepatotoxic and nephrotoxic principles in Terminalia oblongata. Res Vet Sci 50(2):170-177

Francis F, Sabu A, Nampoothiri KM, Ramachandran S, Ghosh S, Szakacs G, Pandey A (2003) Use of response surface methodology for optimizing process parameters for the production of a-amylase by Aspergillus oryzae. Biochem Eng J 15(2):107-115

Garg SK, Tripathi M, Srinath T (2012) Strategies for chromium bioremediation of tannery effluent. In: Reviews of environmental contamination and toxicology. Springer, Berlin, vol. 217, p. 75-140

Garg SK, Singh K, Tripathi M (2015) Optimization of process variables for hexavalent chromium biosorption by psychrotrophic Pseudomonas putida SKG-1 isolate. Desalin Water Treat 57:19865-19876

Hagerman AE, Butler LG (1989) Choosing appropriate methods and standards for assaying tannin. J Chem Ecol 15(6):1795-1810

Hernandez MC, Esquivel JC, Lara F, Rodríguez R, Aguilar CN (2005) Isolation and evaluation of tannin-degrading fungal strains from the Mexican desert. Z Naturforschung C 60(11-12):844-888

Ilori MO, Adebusoye SA, Amund O, Oyetoran BO (2007) A study of tannic acid degradation by soil bacteria. Pak J Biol Sci 10(18):3224-3227

Jadhav U, Kadu S, Thokal N, Padul M, Dawkar V, Chougale A, Salve A, Patil M (2011) Degradation of tannic acid by cold-adapted Klebsiella sp. NACASA 1 and phytotoxicity assessment of tannic acid and its degradation products. Environ Sci Pollut Res 18(7):1129-1138

Karaca H, Tay T, Kıvanç M (2010) Kinetics of lead ion biosorption from aqueous solution onto lyophilized Aspergillus niveus. Water Pract Technol 5(1):2010020

Khambhaty Y, Mody K, Basha S, Jha B (2009) Kinetics, equilibrium and thermodynamic studies on biosorption of hexavalent chromium by dead fungal biomass of marine Aspergillus niger. Chem Eng J 145(3):489-495

Liong MT, Shah NP (2005) Optimization of cholesterol removal by probiotics in the presence of prebiotics by using a response surface method. Appl Environ Microbiol 71(4):1745-1753

Lu YY, Yang JL (1995) Long-term exposure to chromium (VI) oxide leads to defects in sulfate transport system in chinese hamster ovary cells. J Cell Biochem 57(4):655-665

Mabrouk EM, Arayes MA, Sabry SA (2014) Hexavalent chromium reduction by chromateresistant haloalkaliphilic Halomonas sp. M-Cr newly isolated from tannery effluent. Biotechnol Equip 28(4):659-667

Mahadevan A, Muthukumar G (1980) Aquatic microbiology with reference to tannin degradation. Hydrobiologia 72(1-2):73-79
Mahmood S, Khalid A, Mahmood T, Arshad M, Ahmad R (2013) Potential of newly isolated bacterial strains for simultaneous removal of hexavalent chromium and reactive black-5 azo dye from tannery effluent. J Chem Technol Biotechnol 88(8):1506-1513

Manasi D, Lolly J (2014) Biosorption of Cr(VI) by Aspergillus niger. Bionano Front 7(2):36-38

Masood F, Malik A (2011) Hexavalent chromium reduction by Bacillus sp. strain FM1 isolated from heavy-metal contaminated soil. Bull Environ Contam Toxicol 86(1):114-119

Melo AG, Pedroso RC, Guimar LH, Alves JG, Dias ES, de Resende ML, Cardoso PG (2014) The optimization of Aspergillus sp. GM4 tannase production under submerged fermentation. Adv Microbiol 4:143-150

Michalak I, Marycz K, Basińska K, Chojnacka K (2014) Using SEM-EDX and ICP-OES to investigate the elemental composition of green macroalga Vaucheria sessilis. Sci World J 2014:891928. doi:https://doi. org/10.1155/2014/891928

Mishra A, Malik A (2012) Simultaneous bioaccumulation of multiple metals from electroplating effluent using Aspergillus lentulus. Water Res 46(16):4991-4998

Mohan SK, Viruthagiri T, Arunkumar C (2013) Application of Plackett-Burman design for screening the media components for tannase production from redgram husk using submerged fermentation. Int J Pharm Res Rev 2(9):24-29

Mohan SK, Viruthagiri T, Arunkumar C (2014) Statistical optimization of process parameters for the production of tannase by Aspergillus flavus under submerged fermentation. 3 Biotech 4(2):159-166

Mondal KC, Pati BR (2000) Studies on the extracellular tannase from newly isolated Bacillus licheniformis KBR 6. J Basic Microbiol 40(4):223-232

Murugan K, Al-Sohaibani SA (2010) Biocompatible removal of tannin and associated color from tannery effluent using the biomass and tannin acyl hydrolase (EC 3.1. 1.20) enzymes of mango industry solid waste isolate Aspergillus candidus MTTC 9628. Res J Microbiol. 5(4):262-271

Paranthaman R, Vidyalakshmi R, Murugesh S, Singaravadivel K (2009) Optimization of various culture media for tannase production in submerged fermentation by Aspergillus flavus. Adv Biol Res 3(1-2):34-39

Prasenjit B, Sumathi S (2005) Uptake of chromium by Aspergillus foetidus. J Mater Cycles Waste Manag 7(2):88-92

Pulimi M, Jamwal S, Samuel J, Chandrasekaran N, Mukherjee A (2012) Enhancing the hexavalent chromium bioremediation potential of Acinetobacter junii VITSUKMW2 using statistical design experiments. J Microbiol Biotechnol 22:1767-1775

Raghuwanshi S, Dutt K, Gupta P, Misra S, Saxena RK (2011) Bacillus sphaericus: the highest bacterial tannase producer with potential for gallic acid synthesis. J Biosci Bioeng 111(6):635-640

Rodriguez-Duran LV, Contreras-Esquivel JC, Rodríguez R, Prado-Barragán LA, Aguilar CN (2011) Optimization of tannase production by Aspergillus niger in solid-state packed-bed bioreactor. J Microbiol Biotechnol 21(9):960-967

Sethuraman P, Balasubramanian N (2010) Removal of Cr(VI) from aqueous solution using Bacillus subtilis, Pseudomonas aeruginosa and Enterobacter cloacae. Int J Eng Sci Technol 2(6):1811-1825

Sharma S, Adholeya A (2012) Hexavalent chromium reduction in tannery effluent by bacterial species isolated from tannery effluent contaminated soil. J Environ Sci Technol 5(3):142

Sharma S, Agarwal L, Saxena RK (2007) Statistical optimization for tannase production from Aspergillus niger under submerged fermentation. Indian J Microbiol 47(2):132-138

Shugaba A, Wuyep PA, Nok AJ, Ameh DA, Lori JA (2010) Bioremediation of hexavalent chromium and tannic acid in synthetic tannery wastewater using free and calcium alginate-immobilized spores and mycelia of Aspergillus niger and Aspergillus parasiticus. Biorem J 14(3):142-149

Singanan M, Abebaw A, Singanan V (2007) Studies on the removal of hexavalent chromium from industrial wastewater by using biomaterials. EJEAF Che 6(11):2557-2564

Smrithi A, Usha K (2012) Isolation and characterization of chromium removing bacteria from tannery effluent disposal site. Int J Adv Biotechnol Res 3(3):644-652

Srivastava S, Thakur IS (2006) Isolation and process parameter optimization of Aspergillus sp. for removal of chromium from tannery effluent. Bioresour Technol 97(10):1167-1173 
Sultan S, Hasnain S (2007) Reduction of toxic hexavalent chromium by Ochrobactrum intermedium strain SDCr-5 stimulated by heavy metals. Bioresour Technol 98(2):340-344

Tunali S, Kiran I, Akar T (2005) Chromium (VI) biosorption characteristics of Neurospora crassa fungal biomass. Miner Eng 18(7):681-689

Tunali S, Cabuk A, Akar T (2006) Removal of lead and copper ions from aqueous solutions by bacterial strain isolated from soil. Chem Eng J 115(3):203-211

Venil CK, Mohan V, Lakshmanaperumalsamy P, Yerima MB (2011) Optimization of chromium removal by the indigenous bacterium Bacillus spp REP02 using the response surface methodology. ISRN Microbiol 2011:951694
Verma N, Bansal MC, Kumar V (2011) Scanning electron microscopic analysis of Aspergillus niger pellets and biofilms under various process conditions. Int J Microbiol Res 2(1):08-11

Wu YR, He TT, Lun JS, Maskaoui K, Huang TW, Hu Z (2009) Removal of benzo [a] pyrene by a fungus Aspergillus sp. BAP14. World J Microbiol Biotechnol 25(8):1395-1401

\section{Submit your manuscript to a SpringerOpen ${ }^{\odot}$ journal and benefit from:}

- Convenient online submission

- Rigorous peer review

- Open access: articles freely available online

- High visibility within the field

- Retaining the copyright to your article

Submit your next manuscript at $\boldsymbol{\nabla}$ springeropen.com 